\title{
CRP Gene
}

National Cancer Institute

\section{Source}

National Cancer Institute. CRP Gene. NCI Thesaurus. Code C60649.

This gene plays a role in immune and inflammatory processes. 